\title{
FAKTOR PENYEBAB PERILAKU MALADMINISTRASI BIROKRASI DI INSTITUSI PEMERINTAH DI KOTA PEKANBARU PROVINSI RIAU
}

\author{
Rodi Wahyudi \\ Dosen Fakultas Ekonomi dan Ilmu Sosial \\ Universitas Islam Negeri Sultan Syarif Kasim Riau \\ email: radhiallah@yahoo.co.id \\ Jalaluddin Abdul Malek \\ Pusat Pengajian Sosial, Pembangunan dan Persekitaran \\ Fakulti Sains Sosial dan Kemanusiaan Universiti Kebangsaan Malaysia \\ email: drlaar96@gmail.com

\begin{abstract}
Azmi Aziz
Pusat Pengajian Sosial, Pembangunan dan Persekitaran

Fakulti Sains Sosial dan Kemanusiaan Universiti Kebangsaan Malaysia

email: azmiaziz68@yahoo.com
\end{abstract}

\begin{abstract}
Abstrak
Pelayanan publik merupakan proses menyediakan kemudahan dalam setiap aspek kehidupan rakyat oleh pemerintah pusat dan daerah. Prinsip utama dalam pelayanan publik adalah sejauhmana kemampuan pegawai dalam memberikan kemudahan kepada masyarakat yang berurusan di kantor pemerintah. Persoalannya adalah mengapa masih begitu mudah terjadi perilaku maladministrasi dalam birokrasi pemerintah di Kota Pekanbaru, Provinsi Riau ?. Tujuan penelitian ini adalah meneliti faktor penyebab terjadinya perilaku maladministrasi birokrasi di institusi pemerintah yang menyediakan pelayanan dokumen yang melakukan kontak langsung kepada masyarakat. Kuesioner penelitian telah diisi oleh 250 orang pegawai yang bekerja di Kantor Dinas Kependudukan dan Pencatatan Sipil, Kantor Badan Pelayanan Terpadu dan Penanaman Modal, Kantor Imigrasi Kelas I, Kantor SAMSAT dan pegawai kantor Camat di Kota Pekanbaru. Hasil analisis kuantitatif dalam penelitian ini diperkuat dengan data wawancara terhadap 5 orang key informan. Hasil penelitian menunjukkan bahwa perilaku maladministrasi birokrasi disebabkan oleh budaya buruk birokrasi yang turun temurun, adanya pegawai buangan yang memiliki produktivitas kerja yang rendah serta rendahnya kesadaran diri pegawai dalam meningkatkan kualitas pelayanan .
\end{abstract}

Kata Kunci: Pelayanan Publik, Birokrasi, Maladministrasi.

\section{PENDAhuluan}

Di negara manapun birokrasi memiliki peran penting dalam menjalankan berbagai tugas pemerintahan suatu negara. Birokrasi tidak hanya menjalankan perannya dalam memberikan pelayanan tetapi juga melaksanakan keputusan politik pemerintah dalam mewujudkan tujuan dan cita-cita negara. Birokrasi pemerintah memiliki beberapa fungsi utama yaitu menjamin keamanan, memelihara ketertiban, menjamin keadilan, menyediakan pelayanan publik dan meningkatkan kesejahteraan rakyat. Rakyat Indonesia senantiasa berharap supaya 
birokrasi pemerintah berusaha untuk meningkatkan tahap kualitas hidup masyarakat dari segi peluang meningkatkan tingkat pendidikan, tingkat pendapatan, menyediakan layanan kesehatan, fasilitas publik dan kemudahan untuk mengamalkan ajaran agama berdasarkan keyakinan rakyat masing-masing. Rakyat Indonesia juga berharap agar birokrasi pemerintah memiliki rasa cinta dan sayang kepada rakyat, suka memudahkan urusan masyarakat, bahagia melihat rakyat hidup senang dan merasa susah hati melihat kesusahan, kemiskinan dan penderitaan rakyat.

Sejak era reformasi pada tahun 1998 sampai saat ini, birokrasi pemerintahan di Indonesia nampaknya belum banyak mengalami kemajuan yang signifikan. Era reformasi di Indonesia ditandai dengan adanya perubahan dalam berbagai aspek kehidupan seperti sistem politik, sistem hukum, termasuk juga perubahan sistem pemerintahan yang semula bersifat terpusat menjadi sistem pemerintahan otonomi daerah. Undang-Undang Dasar tahun 1945 dan Pancasila merupakan dasar negara Indonesia untuk dijadikan pedoman dalam merumuskan dan menetapkan kebijakan negara. Sedangkan Undang-Undang No. 25 Tahun 2009 pula sebagai sumber hukum dan pedoman pelaksanaan pelayanan publik yang berkualitas oleh setiap pegawai pemerintah. Jumlah pegawai negeri sipil yang bertanggung jawab melaksanakan kebijakan pemerintah adalah 4.646.351 orang (Badan Kepegawaian Negara 2012). Selain itu, potensi sumber daya alam yang luas dan ditambah lagi letak strategis negara Indonesia di Asia Tenggara merupakan peluang besar bagi negara Indonesia untuk bangkit menjadi negara maju. Mewujudkan masyarakat yang adil dan makmur, beriman dan bertakwa sebagai cita-cita mulia bangsa Indonesia sangat ditentukan oleh peran birokrasi pemerintah

\section{PERSOALAN PENELITIAN}

Berdasarkan laporan yang ditulis oleh Ombudsman Republik Indonesia (2013) bahwa masyarakat membuat laporan melalui surat, mengisis formulir di kaunter, datang langsung ke kantor Ombudsman, melapor melalui laman web, email, telefon dan faksimili. Jumlah keseluruhan laporan masyarakat kepada Ombudsman pada tahun 2013 adalah 5173 laporan. Permasalahan yang sering dikeluhkan masyarakat adalah penundaan waktu pelayanan (50.19 \%), penyalahgunaan wewenang $(17.74 \%)$, tidak adil dalam layanan $(10.15 \%)$, layanan tidak mengikut SOP $(7.78 \%)$, pegawai yang memberikan layanan tidak profesional $(4,65$ $\%)$, meminta uang bayaran lebih (3.98 \%) dan tidak memberikan layanan $(2.66 \%)$.

Miftah Thoha (2012) menyatakan bahwa pegawai pemerintah dalam memberikan pelayanan kepada rakyat bersifat sombong, bekerja di kantor pemerintah dijadikan sebagai simbol kekuasaan, rakyat yang datang ke kantor disuruh antri panjang, tidak ada kepastian kapan urusan akan selesai. Sifat pegawai pemerintah tidak memiliki rasa empati kepada rakyat, tidak disediakan ruang menunggu yang nyaman, bahkan masih ada kantor yang membiarkan masyarakat berdiri diterik matahari seperti ikan pindang yang dijemur ditengah matahari panas. Adang Budiman et.al (2013) pula berpendapat bahwa perilaku korupsi dalam birokrasi pemerintah sudah terjadi sejak era Presiden Suharto dan bahkan sudah menjadi kebiasaan rutin serta telah menjadi aktiviti harian mereka ketika bekerja di kantor. Alasan utama mereka melakukan korupsi ketika bekerja yaitu gaji yang diterima tidak mencukupi, rasa tanggungjawab terhadap pekerjaan sangat rendah dan atasan yang mencontohkan perilaku korupsi kepada bawahan. Perilaku buruk birokrasi tersebut masih terus terjadi sampai sekarang. 
Menurut hasil penelitian Komisi Pemberantasan Korupsi (KPK) terhadap 136 unit layanan di pemerintah pusat, 39 unit pelayanan di 10 pemerintah provinsi dan 196 unit pelayanan di pemerintah kabupaten/kota di Indonesia mendapati bahwa $25.0 \%$ dari 11.413 responden menyatakan mereka memberikan biaya tambahan pada waktu berurusan dengan pegawai. Dari $25.0 \%$ responden yang memberikan biaya tambahan, $30.0 \%$ memberikan uang tambahan lebih dari sekali. Sebanyak $96.0 \%$ responden mengatakan bahwa biaya tambahan diberikan dalam bentuk uang dan $34.0 \%$ masyarakat memberikan uang tambahan kerana diminta secara langsung oleh pegawai pemerintah (KPK 2010).

Beberapa hasil laporan dan penelitian bias dijadikan sebagai gambaran yang menunjukkan bahawa maladministrasi birokrasi dalam pelayanan public masih menjadi masalah yang dihadapi oleh masyarakat. Persoalannya adalah mengapa masih begitu mudah berlakunya perilaku buruk birokrasi seperti kelalaian birokrasi menyelesaikan dokumen, penyalahgunaan kuasa, perilaku korupsi, urusan berbelit-belit, tidak ramah kepada masyarakat, tidak ada kejelasan dari segi syarat, biaya dan waktu penyelesaian?

\section{MALADMINISTRASI BIROKRASI}

Konsep maladministrasi birokrasi lahir pada akhir abad ke-19 sebagai istilah yang menunjukkan kegagalan birokrasi dalam mengurus urusan rakyat, kurang inisiatif dan kurang sifat tanggungjawab dari pegawai pemerintah. Penelitian mengenai fenomena maladministrasi birokrasi telah dimulai sejak tahun 1917 oleh seorang ilmuan dari Inggeris bernama Hayward. Beliau telah melakuan penelitian tentang fenomena maladministrasi di Inggeris dan hasil kajian tersebut ditulis dalam buku Professionalism and Originality. Hayward (1917) memaparkan bahwa sejak pekerjaan sebagai pegawai pemerintah termasuk dalam kategori pekerjaan profesional, maka pegawai pemerintah yang bekerja dalam institusi birokrasi dituntut untuk bekerja dengan profesional dan bertanggungjawab. Pegawai pemerintah merupakan pelaksana kebijakan politik negara dan mereka dibayar gaji oleh negara. Kebiasaan buruk yang dilakukan oleh pegawai pemerintah oleh Hayward disebut maladministrasi. Maladministrasi birokrasi digambarkan sebagai sikap menyalahi undang-undang, korupsi , kecuaian, kejahatan, sifat kasar terhadap masyarakat, ketidakadilan, tidak mampu bekerja dan korupsi.

Konsep maladministrasi birokrasi semakin berkembang setelah berdirinya institusi ombudsman di Scandinavia pada tahun 1950. Ombudsman adalah satu institusi pemerintah yang berfungsi untuk menerima laporan pengaduan dari masyarakat atas dugaan ketidakpuasan mereka menerima pelayanan publik. Selepas tahun 1960, pemerintah Inggeris pula mendirikan institusi ombudsman. Antara sebab disusun draf rancangan undang-undang Ombudsman adalah masalah maladministrasi birokrasi yang harus segera diselesaikan di Inggeris. Antara jenis maladministrasi birokrasi yang berleluasa pada masa itu ialah tidak adil dalam memberikan pelayanan, kecuaian terhadap tugas, pengabaian tanggungjawab, kelewatan waktu menyelesaikan dokumen, kejahatan dan perilaku buruk lainnya di kantor .

Peters (2003) telah menyenaraikan jenis perilaku maladministrasi birokrasi di Amerika Serikat. Ia telah menulis jenis amalan maladministrasi birokrasi yaitu mencuri barang kantor, penyalahgunaan waktu di tempat kerja, korupsi, penyalahgunaan wewenang di kantor, konflik kepentingan, rendah kompetensi dari aspek teknikal dan kemampuan menejerial yang lemah. Cope (1997) menyatakan bahwa beberapa faktor sebagai penyebab 
maladministrasi birokrasi yaitu korupsi dan rendahnya integritas, konflik dalam internal birokrasi, konflik antar kaum/etnik, tidak ada sifat disiplin dan buruknya hubungan antar pegawai.

Eklund \& Wimelius menyatakan bahwa maladministrasi birokrasi akibat tidak jelas sasaran yang ingin dicapai, tidak ada indikator dalam mengukur prestasi pelayanan, melakukan beberapa pekerjaan sekaligus tanpa berpegang kepada prinsip keutamaan dan tidak melakukan eksperimen sebagai usaha memperbaiki kualitas pelayanan dan tidak mahu meninggalkan program yang sia-sia dan tidak memberi manfaat kepada pegawai atau masyarakat.

Cheung (2001) telah merincikan beberapa bentuk maladministrasi birokrasi yang biasa berlaku dalam kalangan pegawai publik yaitu:

1. sikap tidak mahu memberikan pelayanan kepada masyarakat.

2. mementingkan diri sendiri dan berusaha untuk menunjukkan sifat sebagai penguasa

3. tidak ada sistem penilaian untuk mengevaluasi pekerjaan pegawai

4. perbaikan yang disampaika tidak diterima oleh birokrasi pemerintah

5. terlalu mengutamakan keuntungan peribadi

\section{METODOLOGI PENELITIAN}

Penelitian ini menggabungkan pendekatan kuantitatif dan kualitatif. Variabel perilaku maladministrasi birokrasi diubah jenis maladministrasi yang telah disusun oleh Masthuri (2005). Data diolah menggunakan software SPSS versi 20. Data dianalisis menggunakan uji frekuensi, deskriptif dan uji independent sample t test. Hasil analisis dari data kuantitatif diperdalam dengan data wawancara secara mendalam kepada key informan sebanyak 5 orang. Angket penelitian telah diisi oleh 250 pegawai yang bekerja di lima kantor yaitu kantor Dinas Kependudukan dan Pencatatan Sipil, Badan Pelayanan Terpadu dan Penanaman Modal, kantor Imigresen Kelas I, kantor SAMSAT dan seluruh kantor camat di Kota Pekanbaru. Kantor yang dipilih dalam penelitian ini menyediakan pelayanan secara langsung kepada masyarakat.

\section{HASIL PENELITIAN}

Dari tabel dibawah ini diketahui, lakilaki sebanyak 146 orang (58.4\%), sedangkan perempuan sebanyak 104 orang (41.6\%). Pegawai yang berumur 31-40 tahun sebanyak 72 orang (28.8\%), umur 41-50 tahun sebanyak 63 orang $(25.2 \%)$ dan umur 51 tahun ke atas hanya 35 orang (14.0\%). Sebanyak 120 orang responden yang telah bekerja Setelah era reformasi (16 tahun ke bawah) sebanyak 164 orang (65.6\%) dan bekerja sejak sebelum era reformasi (lebih dari 16 tahun) sebanyak 86 orang (34.4\%). Status pekerjaan responden dalam penelitian ini kebanyakan mereka adalah pegawai negeri sipil iaitu 195 orang (78.0 \%), sedangkan pegawai honorer (tenaga harian lepas) hanya 55 orang $(22.0 \%)$.

\begin{tabular}{|c|c|c|c|}
\hline Demografi & & $\mathrm{N}$ & $\%$ \\
\hline \multirow[t]{2}{*}{ Jantina } & Laki-laki & 146 & 58.4 \\
\hline & Perempuan & 104 & 41.6 \\
\hline \multirow[t]{4}{*}{ Peringkat Umur } & $\begin{array}{l}\text { Umur } 30 \text { tahun } \\
\text { ke bawah }\end{array}$ & 80 & 32.0 \\
\hline & $\begin{array}{l}\text { Umur } 31-40 \\
\text { tahun }\end{array}$ & 72 & 28.8 \\
\hline & $\begin{array}{l}\text { Umur 41-50 } \\
\text { tahun }\end{array}$ & 63 & 25.2 \\
\hline & $\begin{array}{l}\text { Umur } 51 \text { tahun } \\
\text { ke atas }\end{array}$ & 35 & 14.0 \\
\hline \multirow{3}{*}{$\begin{array}{l}\text { Tempoh } \\
\text { Berkhidmat }\end{array}$} & 16 tahun ke & & \\
\hline & $\begin{array}{l}\text { bawah (Setelah } \\
\text { Reformasi) }\end{array}$ & 164 & 65.6 \\
\hline & $\begin{array}{l}\text { Lebih dari } 16 \\
\text { tahun (Sebelum } \\
\text { Reformasi) }\end{array}$ & 86 & 34.4 \\
\hline \multirow[t]{3}{*}{ Status Pekerjaan } & $\begin{array}{l}\text { Pegawai Negeri } \\
\text { Sipil } \\
\text { Pegawai }\end{array}$ & 195 & 78.0 \\
\hline & $\begin{array}{l}\text { Kontrak } \\
\text { (Tenaga Harian } \\
\text { Lepas) }\end{array}$ & 55 & 22.0 \\
\hline & Jumlah & 250 & 100.0 \\
\hline
\end{tabular}


Dengan menggunakan uji deskriptif menunjukkan bahwa jenis perilaku maladministrasi birokrasi di Kota Pekanbaru yang paling buruk adalah kelalaian birokrasi dalam menyelesaikan urusan masyarakat (Mean=6.48) berbanding ketidakadilan birokrasi dalam memberikan layanan (Mean=5.07), penyalahgunaan wewenang birokrasi $($ Mean=5.01) dan perilaku korupsi (Mean=5.15).

\begin{tabular}{lccc}
\hline $\begin{array}{l}\text { Jenis Amalan } \\
\text { Maladministrasi }\end{array}$ & $\mathrm{N}$ & Mean & SD \\
$\begin{array}{l}\text { Kelalaian } \\
\begin{array}{l}\text { Birokrasi } \\
\text { Ketidakadilan }\end{array}\end{array}$ & 250 & 6.48 & 1.45 \\
$\begin{array}{l}\text { Birokrasi } \\
\text { Penyalahgunaan }\end{array}$ & 250 & 5.07 & 1.35 \\
$\begin{array}{l}\text { Wewenang } \\
\begin{array}{l}\text { Birokrasi } \\
\text { Perilaku Korupsi }\end{array}\end{array}$ & 250 & 5.01 & 1.40 \\
\hline
\end{tabular}

\section{Perilaku Maladministrasi Birokrasi Adalah Budaya Buruk Birokrasi Yang Turun Temurun}

Secara normatif pegawai pemerintah menempatkan warga sebagai pihak yang mempunyai hak untuk mendapatkan pelayanan yang berkualitas. Warga negara memiliki hak untuk mendapatkan perlindungan atas hak-haknya, didengar aspirasi dan tuntutannya, sekaligus dipenuhi hajat dan keperluannya sesuai dengan undang-undang nomor 25 tahun 2009 tentang pelayanan publik. Namun, lebih 16 tahun era reformasi di Indonesia dan reformasi birokrasi telah berlangsung selama 9 tahun masih menunjukkan bahwa sikap yang belum berubah.

Harapan rakyat Indonesia setelah runtuhnya era orde baru adalah menata kembali sistem pelayanan publik serta perbaikan perilaku pegawai dalam memberikan layanan kepada masyarakat. Sampai sekarang masyarakat masih harus bersabar dengan perilaku buruk pegawai ketika memberikan pelayanan. Keadaan bukannya bertambah baik, justru budaya pelayanan zaman dulu masih terlanjut sampai hari ini. Pegawai yang telah bekerja sejak zaman orde baru merupakan mereka yang bekerja lebih lama (senior) jika dibandingkan dengan pegawai yang bekerja di kantor pemerintah setelah era reformasi. Dalam tabel 3 menunjukkan bahwa $66.7 \%$ pegawai yang bekerja sejak zaman orde baru memiliki tahap perilaku maladministrasi birokrasi yang lebih tinggi berbanding pegawai yang bekerja setelah masa reformasi (33.3\%). Walaupun telah diberlakukan undang-undang nomor 25 tahun 2009 tentang pelayanan publik, undang-undang nomor 37 tahun 2008 tentang Ombudsman Republik Indonesia, dan peraturan pemerintah nomor 53 tahun 2010 tentang disiplin pegawai negeri sipil, undangundang nomor 5 tahun 2014 tentang Aparatur Sipil Negara. Tetapi mengapa perilaku maladministrasi birokrasi tidak berubah ?. Penyebabnya adalah karena perilaku tersebut telah membudaya dan merupakan perilaku yang turun-temurun sehingga sehingga sangat susah untuk dibersihkan. 


\begin{tabular}{|c|c|c|c|c|c|c|}
\hline \multirow{3}{*}{ Perilaku Maladministrasi Birokrasi } & \multicolumn{4}{|c|}{ Lama Bekerja } & & \\
\hline & \multicolumn{2}{|c|}{$\begin{array}{c}\text { Bekerja Setelah Masa } \\
\text { Reformasi }\end{array}$} & \multicolumn{2}{|c|}{$\begin{array}{c}\text { Bekerja Sejak } \\
\text { Masa Orde Baru }\end{array}$} & \multicolumn{2}{|c|}{ Jumlah } \\
\hline & $\mathbf{N}$ & $\%$ & $\mathbf{N}$ & $\%$ & $\mathbf{N}$ & $\%$ \\
\hline \multirow{2}{*}{\multicolumn{7}{|c|}{$\begin{array}{l}\text { Tahap Perilaku Maladministrasi } \\
\text { Birokrasi }\end{array}$}} \\
\hline & & & & & & \\
\hline \multicolumn{7}{|l|}{ Tahap Rendah (Skor 16-24) } \\
\hline \multirow{2}{*}{ Tahap Tinggi (Skor 25-32) } & & & & & & \\
\hline & 36 & 66.7 & 18 & 33.3 & 54 & 100.0 \\
\hline \multicolumn{7}{|l|}{ Tahap Kelalaian Waktu } \\
\hline \multirow{2}{*}{ Tahap Tinggi (Skor 7-8) } & 75 & 66.4 & 38 & 33.6 & 113 & 100.0 \\
\hline & 89 & 65.0 & 48 & 35.0 & 137 & 100.0 \\
\hline \multicolumn{7}{|l|}{ Tahap Ketidakadilan } \\
\hline Tahap Rendah (Skor 4-6) & 132 & 64.1 & 74 & 35.9 & 206 & 100.0 \\
\hline Tahap Tinggi (Skor 7-8) & 32 & 72.7 & 12 & 27.3 & 44 & 100.0 \\
\hline \multicolumn{7}{|l|}{ Tahap Penyalahgunaan Wewenang } \\
\hline \multicolumn{7}{|l|}{ Tahap Rendah (Skor 4-6) } \\
\hline Tahap Tinggi (Skor 7-8) & 32 & 74.4 & 11 & 25.6 & 43 & 100.0 \\
\hline
\end{tabular}

Tahap Perilaku Korupsi

Tahap Rendah (Skor 4-6)

Tahap Tinggi (Skor 7-8)

$\begin{array}{llllll}126 & 63.3 & 73 & 36.7 & 199 & 100.0 \\ 38 & 74.5 & 13 & 25.5 & 51 & 100.0\end{array}$

Apabila pegawai yang bekerja sejak zaman orde baru memiliki tahap perilaku maladministrasi birokrasi yang lebih tinggi berbanding pegawai yang bekerja setelah masa reformasi. Dominasi budaya kerja pegawai yang bekerja sejak zaman orde baru terhadap pegawai yang bekerja setelah masa reformasi jelas akan mempengaruhi usaha untuk memperbaiki kualitas pelayanan publik.

Ciri budaya birokrasi yang cukup mencolok pada zaman orde baru adalah menganggap diri mereka sebagai penguasa bukan sebagai pelayan. Seharusnya pegawai pemerintah merasa bahwa keberadaanya di kantor adalah untuk membantu memudahkan urusan masyarakat, menyediakan dokumen yang diperlukan masyarakat dan menyelesaikan dokumen tersebut sesuai dengan waktu yang telah ditetapkan oleh undang-undang. Saya adalah pelayan sedangkan masyarakat adalah raja dan sebagai pelayan yang baik harus memberikan layanan yang terbaik kepada raja. Budaya birokrasi yang menganggap diri mereka sebagai penguasa juga telah wujud di zaman penjajahan Belanda. Kata administrasi dalam bahasa Belanda yaitu beheer atau bestuur yang berarti penguasa. Makna inilah yang diamalkan oleh penjajah terhadap rakyat Indonesia.

Budaya buruk birokrasi yang turuntemurun turut diakui oleh Pak Hendri Kumar, pegawai Badan Kepegawaian Daerah Provinsi Riau, beliau mengatakan:

"Pegawai yang bekerja sejak era Suharto memang banyak tahu tentang sistem administrasi dan manajemen organisasi, tetapi mereka memiliki penyakit kerusakan moral yang parah. Apabila ada pegawai baru yang memiliki sifat baik, jujur dan bertanggungjawab diterima di kantor, maka tidak ada jaminan bahwa dia bias merubah budaya organisasi. Ibarat 100 liter air keruh kemudian ditambahkan 1 liter air bersih, air tersebut masih dalam keadaan keruh. Yang 
lebih bahaya lagi adalah pegawai yang status quo (lama) dan telah mendapat banyak manfaat dari keadaaan budaya birokrasi yang buruk ini, mereka tidak akan memberi kesempatan kepada pegawai jujur untuk melakukan perubahan. Pegawai lama yang terbiasa dengan perilaku buruk mengatakan pegawai baru yang jujur tersebut tak bisa dipakai, kecuali pegawai baru tersebut mau mengikuti budaya kerja seperti yang sudah ada”.

Hasil penelitian telah mendukung hasil penelitian Adang Budiman et. al (2013) dari Universiti Queensland Australia. Mereka telah melakukan kajian tentang perilaku korupsi pegawai pemerintah pada era Presiden Suharto. Mereka telah mengumpulkan data melalui indept interview terhadap 30 orang pejabat pemerintah untuk mendapatkan data mengenai apakah faktor yang mempengaruhi perilaku korupsi ?. hasil wawancara dari key informan kajian menunjukkan bahwa perilaku korupsi pada era Presiden Suharto telah menjadi rutinitas harian mereka ketika bekerja di kantor. Penyebabnya adalah rendahnya gaji yang diterima, rasa tanggungjawab terhadap pekerjaan sangat rendah dan pemimpin yang juga terlibat korupsi.

\section{Perilaku Maladministrasi Birokrasi Dilakukan oleh Pegawai Buangan}

Adanya pegawai buangan di kantor pemerintah telah menjadi musibah besar bagi internal birokrasi dan masyarakat. Biasanya suatu benda yang masuk dalam kategori buangan menunjukkan bahwa benda tersebut tidak bernilai atau sampah yang harus keluarkan untuk selanjutnya dimasukkan dalam tong sampah, dikubur atau dibakar. Istilah pegawai buangan ini, diperoleh dari hasil wawancara bersama Pak Dasuki (Staf Ombudsman Wilayah Riau) dan Pak Baharudin (Kepala Dinas Kependudukan dan Pencatatan Sipil) yang mengatakan pegawai buangan adalah pegawai pemerintah yang tidak memiliki kompetensi diri, tidak memiliki kelayakan dan tidak ada kemampuan bekerja secara profesional. Mereka inilah yang sumber masalah di kantor-kantor pemerintah. Apa artinya job description, standard operational procedure kalau si pegawai tidak bisa melaksanakan tugas sebagaimana yang telah diperintahkan oleh atasan. Ciri pegawai buangan adalah tidak akan menyegerakan urusan masyarakat selagi tidak ada arahan dari atasan. Padahal, setiap mereka telah diberikan tugas dan tanggungjawab masing-masing tanpa harus menunggu arahan daripada pihak atasan.

Mengapa ada pegawai buangan di kantor pemerintahan Kota Pekanbaru? Atau tidak tertutup kemungkinan juga di kantor lain diluar Kota Pekanbaru di Indonesia ?.

Kita kembali lagi pada sejarah masa lalu, penambahan jumlah pegawai pemerintah secara besar-besaran pada era pemerintahan orde baru bertujuan untuk menyediakan lowongan kerja di bidang pemerintahan. Selama pemerintahan orde baru berkuasa, pemerintah berusaha membuka lowongan pekerjaan sebagai pegawai pemerintah sehingga melebihi keperluan. Tujuan penerimaan pegawai pemerintah adalah untuk menguatkan dukungan terhadap kekuatan partai penguasa (Partai Golkar), sehingga aspek kompetensi diri calon pegawai kurang diberi perhatian. Penerimaan pegawai pemerintah dalam jumlah besar adalah memenangkan pemilu dengan memanfaatkan suara dari golongan birokrasi pemerintah. Pegawai pemerintah tidak dibenarkan untuk memilih partai selain Golkar dalam pemilu, jika ketahuan maka diberi hukuman atau pindahkan ke kawasan pedalaman.

Penerimaan pegawai pemerintah dalam organisasi pemerintah terus-menerus dilakukan tanpa memperhatikan aspek profesionalisme dan keperluan organisasi. Akibat dari jumlah pegawai publik yang terlalu besar dan tidak profesional, maka 
hasilnya adalah banyak pegawai buangan dalam birokrasi pemerintah. Mereka hanya manjadi beban negara untuk membayar gaji, padahal sumbangan mereka untuk kemajuan negara dan daerah masih sangat kecil. Kesalahan sistem rekrutmen pegawai pada masa lalu telah menyebabkan wujudnya pegawai yang tidak memiliki kompetensi tetapi tetap diterima sebagai pegawai negeri sipil. Selain disebabkan faktor kepentingan politik era orde baru, faktor lain yang menyebabkan adanya pegawai buangan adalah:

a. Diterima sebagai pegawai bukan atas prinsip kompetensi tetapi kerana ada hubungan keluarga, suku, kampong, teman (nepotisme) atau kerana disogok.

b. Biasanya yang memiliki kompetensi dan professional lebih memilih bekerja di perusahaan swasta sebab gaji yang diterima lebih besar berbanding gaji sebagai pegawai pemerintah.

Berdasarkan hasil wawancara dengan Pak Teguh (Pegawai Kementerian Pendayagunaan Aparatur Negara dan Reformasi Birokrasi), beliau mengatakan: "sebenarnya masalah awalnya adalah ketika rekrutmen pegawai dalam perencanaan penerimaan pegawai. Berapa jumlah pegawai yang mau diterima? selanjutnya, kualifikasi seperti apa yang diperlukan?. Ketika pemerintah kurang memperhatikan aspek kualitas, hanya mahu menambah pegawai, maka muncullah pegawai yang tidak ada kompetensi. Misalnya, apa potensi yang ada di Riau dan Kota Pekanbaru, seperti minyak bumi, hasil perkebunan, sumber laut. Seharusnya dicari pegawai yang bisa mengembangkan potensi yang ada di daerah. Jangan hanya asal terima pegawai saja”.

Menurut Pak UU Hamidy, seorang budayawan di Kota Pekanbaru ketika diwawancara, beliau mengatakan bahwa:
"Adanya pegawai buangan dalam agensi pemerintah Kota Pekanbaru disebabkan kerana mana-mana kantor yang tidak berhubungan dengan uang (kecil peluang untuk mendapatkan uang tambahan/korupsi) menjadi tempat pembuangan pegawai yang tidak disukai oleh pihak atasan. Selain itu, pegawai bekerja tidak sesuai dengan bidang kepakaran/ijazah yang dimilikinya serta terlalu sering pindah tugas sehingga belum lagi sempat berbuat apa-apa sudah dipindahkan".

Apa yang dilakukan apabila di kantor pemerintah ada pegawai buangan ?. Yang harus dilakukan adalah bagaimana meningkatkan kompetensi mereka sehingga betul-betul melaksanakan tugas dan tanggungjawab dengan sebaik-baiknya dengan harapan masyarakat merasa puas dengan pelayanan yang mereka terima. Beberapa aspek yang perlu ditingkatkan berhubungan dengan kompetensi pegawai adalah aspek pengetahuan sesuai dengan bidang pekerjaan, pengamalan nilai agama, meningkatkan motivasi diri untuk sukses dalam karier, memupuk inisiatif dan kreatif dalam bekerja. Hal ini sesuai dengan pendapat Akram dan Tehrani (2011) yang mengatakan bahwa kemampuan untuk melaksanakan suatu pekerjaan yang dilandasi oleh kemahiran dan pengetahuan serta didukung oleh sikap disiplin dalam bekerja sebagaimana yang diatur dalam etika kepegawaian.

Apabila kompetensi semakin baik, akan lahir kesadaran diri sebagai pelayan masyarakat yaitu sifat tanggungjawab dengan dedikasi tinggi dan sikap mahu menyumbangkan tenaga yang lebih, supaya bukan saja dapat menyelesaikan tugas-tugas yang dibebankan kepadanya seperti yang ada dalam list tugasnya, tetapi juga sanggup melakukan kerja lebih untuk meningkatkan kualitas pelayanan publik di kantor. Hal ini sejalan dengan pendapat Abdullah (1979) bahw seorang pegawai yang memiliki 
kesedaran diri yang baik tidak akan berpuas hati melakukan kerja pada tahap minimal. Sebaliknya ia akan mencoba sedayaupayanya memenuhi waktu kantor, bahkan siap untuk lembur untuk menyelesaikan masalah-masalah kantor berkaitan dengan pelayanan yang hendak diberikan kepada masyarakat. Ia senantiasa menjaga waktu supaya tidak terbuang. Seorang pegawai yang memiliki kesedaran diri senantiasa menunjukkan inisiatif untuk memecahkan sesuatu masalah. Ia cuba menggunakan kebijaksanaanya untuk memikirkan penyelesaian setiap masalah dan membuat keputusan dengan bijaksana.

\section{PENUTUP}

Untuk meningkatkan kualitas pelayanan publik tidak cukup hanya dengan mengubah peraturan perundang, tetapi harus diikuti oleh perubahan perilaku, perubahan mind set pegawai yang akan melaksanakan peraturan perundang tersebut. Apa yang terjadi dalam sistem administrasi dan pelayanan publik di Indonesia adalah masih sekedar perubahan peraturan perundang, terbukti perilaku maladministrasi birokrasi di Kota Pekanbaru sebagai bukti bahwa maladministrasi birokrasi masih gagal diatasi. Perubahan perilaku pegawai sebaiknya diawali dengan meningkatkan pengetahuan dan kesadaran diri untuk meningkatkan kualitas pelayanan publik.

\section{DAFTAR PUSTAKA}

Abdullah Bin Mohd Salleh. 1979. Panduan Perkhidmatan Cemerlang. Kuala Lumpur: Jabatan Perdana Menteri.

Adang Budiman, Amanda Roan \& Victor J, Callan. 2013. Rationalizing Ideologies, Social Identities and Corruption Among Civil Servants in Indonesia During the Suharto Era. Journal Bussiness Ethics, 116:139149.

Akram dan Tehrani. 2011. Predicting Model of Organizational Identity toward its effect on Organizational Citizenship Behavior. African Journal of Business Management, 5 (23): 9877-9888.

Cheung, A. B. L. 2001. Civil Service Reform in Post-1997 Hong Kong: Political Challenges, Managerial Responses?. International Journal of Public Administration, 24: 929-938.

Cope, G. H. 1997. Bureaucratic Reform and Issues of Political Responsiveness,Journal of Public Administration Research and Theory, 20:461-470.

Eklund, N., \& Wimelius, M. E. 2008.Globalization,

Europeanization and Administrative Reform. Dalam J. Killian, \& N. Eklund. (Eds), Handbook of Administrative Reform. Boca Raton: Auerbach Publication.

Hayward, F. H. 1917. Professionalism and Originality. London: Allen \& Unwin.

Komisi Pemberantasan Korupsi. 2010. Integritas Sektor Publik Indonesia, Fakta Korupsi Dalam Pelayanan Publik. Jakarta: Direktorat Penelitian dan Pengembangan Kedeputian Bidang Pencegahan Komisi Pemberantasan Korupsi. 
Masthuri. 2005. Mengenal Ombudsman Indonesia. Jakarta: Penerbit Pradnya Paramita.

Miftah Thoha. 2012. Birokrasi Pemerintah dan Kekuasaan di Indonesia. Yogyakarta: Penerbit Thafa Media.

Ombudsman Republik Indonesia. 2013. Kepatuhan Pemerintah Daerah Kota Pekanbaru dalam Pelaksanaan UU 25 Tahun 2009 tentang Pelayanan Publik. Penerbit: Ombudsman Republik Indonesia Kantor Perwakilan Provinsi Riau.

Peter Carey.1986. Ekologi Kebudayaan Jawa dan Kita Kedung Kebo. Jakarta: Pustaka Azet.

Undang-Undang Nombor 37 Tahun 2008 Tentang Ombudsman Republik Indonesia.

Undang-Undang Nomor 25 Tahun 2009 Tentang Pelayanan Publik

Undang-Undang Nomor 5 Tahun 2014 Tentang Aparatur Sipil Negara 